\title{
A New And Better Way To Measure The Cost Of Equity Capital For Small Closely Held Firms
}

Denis O. Boudreaux, University of Louisiana, USA Spuma Rao, University of Louisiana, USA Jim Underwood, University of Louisiana, USA Nancy Rumore, University of Louisiana, USA

\begin{abstract}
The purpose of this paper is to explore the theoretical structure that underlies the valuation process for small closely held firms. Specifically, cost of capital estimate methods which appear in the current literature are examined, and a theoretically correct and simple method to measure cost of equity capital for privately held companies is offered.
\end{abstract}

Keywords: New Approach for Cost of Equity Capital; Return on Investment for Small Firms; Build Up Model for Measuring Cost of Equity

\section{INTRODUCTION}

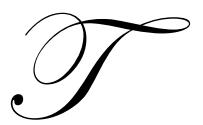

he purpose of this paper is to explore a theoretical structure that underlies the valuation process for business damage cases involving small closely held firms. Most current valuation estimate methods employ a discounted cash flow methodology. The models generally rely on predictions of cash flow and cost of capital estimates, tasks that may be quite complex when applied to small privately held firms. This paper critiques cost of capital assessment methods that appear in the current literature and in practice and proposes a method that could be applied to a study for a small closely held firm. This method is conceptually simple, theoretically correct and fair to all parties.

The need for an economic valuation study for closely held companies result from litigation involving the owners of a firm and its employees, competitors, suppliers, the government or other stakeholder at interest. Litigation necessitating the valuation of closely held firms typically stems from disputes that range from divorce settlements, business dissolutions, estate taxation issues, to those involving business damages such as dissenting stockholder suits, lost business opportunities, breach of contract, antitrust actions, personal injury and insurance claims. Governmental agencies may also condemn or seize business property through eminent domain or appropriation proceedings. In each situation, the value of the firm for at least one particular point in time must be determined.

In litigation forensic economists are usually employed, whether by the plaintiff(s) or the defense, in order to measure the economic damages and produce an independent report. Ideally, the report and/or expert testimony of the economist provides the court or other arbitrator with an unbiased opinion regarding the facts and financial information presented so that an informed ruling or decision can be made. Cases such as those involving divorce, sale or even dissolution usually require the expert to derive the value of the closely held firm "as is". However, cases involving damage analysis often require more stringent assumptions and greater computational effort than other types of valuation tasks because these proceedings require an expert to determine both the value of the firm "as is" and the value "but for" the damage action or incident. In such cases, the value of the firm is first estimated as though the event that adversely affected the business did not happen. This valuation is compared to a second valuation of the damaged firm to determine the economic loss suffered. 
Some Forensic economists measure and report lost profits or reduction in cash flows to quantify damages. A firm's value is a function of its financial structure, its expected cash flows, the firm's cost of capital and the cash flows' risk (Gitman 1994). Theoretically, the firm has been damaged because its value is less than if the event had not happened. The lower value could be the result of not only smaller expected cash flows but also a change in risk and or a change in the firm's financial structure. Thus, it is best to view business damages in the broad context of the firm's decline in value.

\section{THEORY OF BUSINESS IMPAIRMENT}

A variety of events and actions can cause business damages and eventually result in litigious activity. In theory, the value of any business or investment depends on the future benefits that will accrue to the owner(s) over time (Van Horn 1995). In the case of closely held businesses, these future benefits are best measured as the value of the net expected after-tax cash flows available to the owner(s) (Pratt 1996, 1993). In situations where an award for damages constitutes a taxable receipt, firm value should be determined using pre-tax cash flows in order to fairly compensate the recipient (Peterson 2009). All estimated cash inflows and outflows must be discounted to present value at an appropriate rate of return which reflects the relative riskiness of the cash flows, as well as the required rate of return to the stakeholders of the business.

Cash flows in damage cases are typically estimated under two basic scenarios (Gaughan 2009). First, the sales, expenses, profits and other cash flows of the firm may be estimated under the assumption that the firm had not suffered any damages. Second, firm cash flows are estimated under the assumption of its present operations, that is, the firm's expected future operating performance. The difference between the two estimates is the theoretical loss (L). The equations below illustrate a model for the valuation problem for damage cases:

$$
\mathrm{L}=\mathrm{V}_{\mathrm{B}}-\mathrm{V}_{\mathrm{C}}
$$

Where

$$
\begin{array}{ll}
\mathrm{V}_{\mathrm{B}} & =\mathrm{CF}_{\mathrm{Bt}} /(1+\mathrm{k})^{\mathrm{t}} \\
\mathrm{V}_{\mathrm{C}} & =\mathrm{CF}_{\mathrm{Ct}} /(1+\mathrm{k})^{\mathrm{t}}
\end{array}
$$

And

$\mathrm{V}_{\mathrm{B}} \quad=$ value of the firm before it suffered damages (i.e., undamaged),

$\mathrm{V}_{\mathrm{C}} \quad=$ value of the firm given its current economic condition (i.e., damaged),

$\mathrm{CF}_{\mathrm{Bt}}=$ the estimated firm cash flow for year $t$ had it not suffered damages,

$\mathrm{CF}_{\mathrm{Ct}}=$ the estimated firm cash flow for year $t$ given its current economic condition, and

$\mathrm{k}=$ the cost of capital.

If the damages caused the firm to have lower cash flows than in the past, then these lost cash flows should also be included as part of the total loss. Theoretically, these lost cash flows should be compounded and calculated as a future value at the time of settlement. This compound rate would be the opportunity cost of funds for the business, as this is the rate the firm could have made on investments had there been no damage. In most instances, however, the expert employs a required rate of return as the cost of capital due to the relative difficulty in determining opportunity costs.

\section{DIFFERENCES IN VALUATION OF CLOSELY HELD BUSINESSES AND PUBLICLY TRADED FIRMS}

Differences between closely held firms and publicly traded corporations influence valuation methodology. For example, publicly held firms are required to have their financial statements annually audited by certified public accountants, and these statements also are made available to the public. Closely held firms do not have this requirement. Since financial statements are vital in determining expected cash flows, cost of capital and value, and an expert may have to review unaudited financial statements of closely held firms with greater caution (Peterson 
1989). Another key difference in publicly held versus closely held firms has to do with the reality that the cash flows available to owners of closely held firms typically encompass more than mere declared dividends. Such additional flows include salary or other direct and indirect compensation or perks, as well as benefits that may accrue from control over depreciation or similar non-cash expense recognition, among various other types of accounting and/or tax benefits (Pratt 1996).

An important part of the valuation process is the determination of the discount rate to be used in estimating the present value of the cash flow stream. This discount rate is the required rate of return for the primary stakeholders of the firm. For any firm, this would be the weighted average cost of capital, which is estimated from the marginal after-tax costs of debt, preferred stock, and common stock (Van Horn 1995). The cost of capital for a publicly traded firm is the result of arms-length transactions that are empirically observable. For publicly held firms because stock and bond prices are market determined and made known, the cost of capital can easily be estimated (Gitman 1994). These financial transactions are required to be disclosed as public information, whereas closely held firms are under no such obligation. Thus, derivation of an appropriate cost of capital measure is much more difficult for closely held firms than for publicly traded firms.

The components of the applicable cost of capital also differ by type of ownership. First, the cost of debt financing for a closely held firm is usually different (higher) than for a comparable publicly held firm. Closely held firms generally must rely on trade credit and loans or lines of credit from owners and financial institutions such as commercial banks, whereas publicly traded companies may issue more cost effective corporate bonds as well. Even though debt costs are generally higher for the small closely held firm, these costs can be estimated by reviewing loan interest rates and well as the marginal tax rate. Second, the costs of equity also differ for publicly held and closely held firms. For example, investments in publicly held firms generally impose less liquidity risk to owners than do closely held firms. The relative marketability or ease with which an owner may sell their stake in a firm impacts the cost of equity, required returns, and valuation. All things being equal, an interest in a business is worth more if it is readily marketable. Interests in closely held businesses are not liquid relative to most other investments. In valuation cases of closely held firms, both the Internal Revenue Service (see, in particular, Revenue Ruling 59-60) and the courts have consistently recognized that a higher discount rate should be applied to account for the lack of marketability.

An important, related issue pertains to the degree of control the ownership interest in the firm represents. The issue of control is often of prime concern in valuations of small or closely held firms because the trade of any portion of the stock of such firms may comprise a significant, though non-controlling, interest in contrast to that of publicly traded firms. All things being equal, an interest in a business may be worth more if it represents a controlling (majority) interest. Contrary to any fiduciary duty majority owners may owe, holders of a minority interest may be unjustly subjected to policies or practices that may limit the value of their minority position (e.g., excessive salary or compensation for majority owner/managers), and jurisdictions differ in the establishment of rights, privileges and protections afforded minority interest holders. The increase in discount rate attributable to the lack of marketability, in conjunction with the compound problem associated with a minority interest, may be a most difficult issue to resolve.

Differences in equity cost and required returns also may result from portfolio effects that stem from the investment holdings of firm owners. Publicly traded firms are generally owned by investors whose loss is limited to the market value of the shares held. Investors holding well diversified portfolios face a lower level of total risk, and variability in returns, because such diversification reduces the relative impact of company-specific (i.e., unsystematic) risk in their total portfolio of investments. By contrast, owners of closely held firms may be quite poorly diversified, as the bulk of their personal wealth, effort and self-worth may be tied up in their firm. The primary risk facing owners of such firms is the relative variability in returns for that individual firm, with no commensurate total portfolio reduction in unsystematic risk. Therefore, owners of closely held firms often bear greater total risk, and may have higher potential return expectations, than owners of publicly held firms. However, some of these increased expectations may be more easily satisfied by benefits that may be considered somewhat non-economic in nature (e.g., need for prestige or community standing, among others). 


\section{METHODS OF MEASURING COST OF EQUITY CAPITAL}

\section{Build-up Models}

The build-up approach breaks down the cost of equity capital into different components and specifies a percentage for each component (Pratt, et al 2002). Build-up models generally begin with a risk-free rate and add one or many factors based on the risk of the equity instrument. Some of the more common components used In this approach include:

$\begin{array}{ll}\text { - } & \text { risk-free rate } \\ \text { - } & \text { equity risk premium } \\ \text { - } & \text { size premium } \\ \text { - } & \text { country risk premium } \\ \text { - } & \text { other adjustments }\end{array}$

This approach can be expressed as the following model:

$\mathrm{Ke}=\mathrm{Rf}+\mathrm{RPm}+\mathrm{RPs}+\mathrm{RPu}+\mathrm{Rpi}+\mathrm{O}$

Where:

$\mathrm{Ke}=$ expected equity return or cost of equity capital,

$\mathrm{Rf}=$ risk-free rate,

$\mathrm{RPm}=$ equity risk premium for market (general market equity risk premium),

RPs = size premium,

$\mathrm{Rpu}=$ specific company premium (u stands for unsystematic risk),

$\mathrm{Rpi}=$ country risk premium (international investing), and

$\mathrm{O}=$ other adjustments.

The risk-free rate (Rf) is usually estimated by the current yield on the twenty year US Treasury bonds (Brigham and Ehrhardt 2002). This rate is empirically observable. To estimate the market risk premium (RPm), historical yields or Ex post methods are commonly employed. Ibbotson Associates publishes historical risk premium data in its annual Stocks, Bonds Bills and Inflation. This is a source that is often used as the estimate for equity risk premium in the build-up method. Recent studies have provided evidence that the degree of risk and the corresponding cost of capital increase with the decreasing size of the company. The size premium (RPs) is to capture this higher risk and cost. There are no adequate empirical studies to quantify this higher cost for small nonpublicly traded firms. Ibbotson Associates attempts to quantify the higher cost of capital for small firms listed on the New York Stock Exchange (Ibbotson 1998). However, sometimes the yields inverse and the smaller firms have lower yields than larger firms causing theoretical conflicts. Accordingly, the premium is mostly a subjective assignment based on an expert's experience and personal observations. The specific company premium (Rpu) encompass risk relating to the industry in which the company operates in, higher or lower company volatility of return, leverage differences, dependencies on key customers, suppliers, employees, lawsuits and other unsystematic risk factors. The size premium tends to capture most of the unsystematic risk and this adjustment should be for only very unique company factors. This premium is not quantified by research so it must be subjectively estimated.

The primary advantages of the build-up methods are simplicity and conceptualization (Zukin 1990). These models offer the appeal of logic to courts and non-experts. A small closely held firm should probably have a higher cost of equity capital. Also, many of the components are derived from actual, albeit historic, data. This method may be more accurate when applied to very large American companies as many of the factors will not be included in the model (e.g. size premium, specific company premium, country risk premium), reducing the chance for error. The major problems associated with applying these methods to small closely held firms are that the expert has little hard evidence to specifically quantify many of the subjective components. Also, the different components are not perfectly separable and this makes the premiums also not separable. Similar to the nominal rate on a commercial 
bond, the interest rate cannot be broken down with great confidence and precision into a real interest rate, an inflation premium and a risk premium. Corporate bond yields are much less convoluted than required equity returns for small non-publicly held companies.

In most cases, analysts using the build-up model estimate the equity rate of return for a small business to be in excess of 25\% (Boudreaux and Rao 2007). There are many instances where the analysts conclude the equity required return is larger than $35 \%$ for small privately held firms. These estimates are more than likely much larger than what the actual owners expect and require their average annual yield or return to be. If you consider these large required returns as the increase in value or wealth to the owners, then the results are simply staggering and irrational. For example, if a firm has an equity investment of $\$ 500,000$ and the analyst projects that the required rate of return should be $25 \%$, then the value of equity would grow to $\$ 3,761,702,277$ in just 40 years. It is highly unlikely that many equity investments of $\$ 500,000$ in small privately held firms will be worth almost 4 billion dollars. A review of the past 40 years provides support that only a very small numbers of companies experiences such success.

\section{Discounted Cash Flow (DCF) Method}

The single-stage DCF model is based on the Gordon Growth Model (Van Horn 1995). This method measures the required (expected) return on equity. This method heavily relies on the knowledge of the present value of the common stock. The model can be expressed as:

$\mathrm{Ke}=(\mathrm{NCF}(1+\mathrm{g})) /(\mathrm{PV})+\mathrm{g}$

Where:

$\mathrm{Ke}=$ expected equity return or cost of equity capital,

$\mathrm{NCF}=$ recent yearly cash flow to investor for one share (dividend),

$\mathrm{g} \quad=$ expected long-term sustainable growth rate in cash flow to investor, and

$\mathrm{PV}=$ market value of one share of stock.

For a publicly traded company, the variables used in the DCF model are generally accessible (Hitchner 2006). Most important the market value of the stock is easy to observe. Dividends are the rule and not the exception for large companies. Most large publicly held companies use dividends as the normal method to reward equity investors (Stowe 2007). Growth estimates are published in Standard \& Poor's Compustat Analyst's Consensus Estimates database. This database covers most large companies.

The advantage to this method is that it is well known and established as it has been used very successfully by utility companies to request rate adjustments from public utility commissions. The method is mathematically and theoretically pleasing as the Gordon Model defines value correctly as: PV $=(\mathrm{NCF}(1+\mathrm{g})) /(\mathrm{Ke}-\mathrm{g})$. Therefore, Ke must be correctly specified in the cost of capital equation. The disadvantages are for a small privately held firm the stock price is not known with certainty. Therefore, the solution to the cost of capital equation is not precise. Also, small firms may not pay dividends or the dividend it pays may have little to do with earnings. However, cash flow can be used as a substitute. A third problem is the growth rate estimate. This must be a perpetual annual growth rate which is more problematic. Dividends or cash flow will probably grow at different rates over the firm's life cycle. The DCF model is robust and can include the different growth rates, the problem lies in the difficulty in projecting the growth rates (Damodaran 1994).

\section{A PROPOSED METHOD FOR MEASURING COST OF EQUITY CAPITAL FOR A SMALL CLOSELY HELD FIRM}

A hallmark of well-developed financial securities markets is that publicly-traded stocks have been fairly valued in the competitive marketplace by willing buyers and sellers under no compulsion to act, each having reasonable knowledge of all the relevant facts. This concept of fair market value is the most widely accepted basis for valuation in both academic and legal environments [see: O'Malley v. Ames, 197 F.2d 256, 257 ( $8^{\text {th }}$ cir. 1952)]. It is this methodology that should be used to fairly estimate the cost of equity capital for the small closely held firm. 
The analyst should evaluate the economic history of the firm and calculate the adjusted historic return to invested capital (AROI). This actual historic equity return is a theoretical correct calculation of the required return. This model can be expressed as:

$\mathrm{AROI}=\mathrm{EBO} / \mathrm{IC}$

Where:

$\mathrm{EBO}=$ the economic benefits to the owner, and

$\mathrm{IC}=$ the equity invested capital.

The economic benefits to the owners (EBO) are the direct and indirect financial gains as well as monetary perks the owners receive. These "benefits" of ownership are usually calculated in normal valuation analysis to determine past cash flows and estimate expected cash flows for the DCF model.

The economic benefits are found by measuring the firm's cash flow from operations (net income plus depreciation) and adding to this all expenses that are non-earned perks, and include salaries/bonuses that exceed the market rate for similar work. This total is the true economic benefit to the owners.

The invested capital (IC) is the total equity found on the firm's balance sheet. The original equity infusion plus what has been retained during the firm's operations is the owners' equity capital. The total invested capital should be calculated as an average for the same past five years.

The past five year average AROI is the actual average return to the owners of the firm and is theoretically the owners' required rate of return. It has to be their acceptable level of return otherwise the owners would take actions such as selling their ownership interest or divesting certain low earning assets.

\section{EXAMPLE}

For example, a closely held firm has the following five year average: net Income of $\$ 1,000,000$ and depreciation expense of $\$ 400,000$. After analyzing the firm's expenses on average, $\$ 600,000$ are identified as nonearning perks and excess compensation is calculated to be $\$ 800,000$. The average five year AROI is estimated to be $\$ 2,800,000$. The firm's average IC is $\$ 16,000,000$. The AROI is found by equation (6):

$\mathrm{AROI}=\$ 2,800,000 / \$ 16,000,000$

The firm's AROI is $17.5 \%$.

This figure is the best estimate for the cost of equity capital for the small closely held firm. For verification, the owners of the firm should be asked if the calculated AROI is their required and expected rate of return.

\section{CONCLUSION}

The methods most currently used, the build-up approach and DCF method, generally require the analysts to make many assumptions, use unsubstantiated variables and probably end up with a biased estimate. A recent survey revealed that these methods were used to estimate the equity cost of capital during the period 2000 through 2006 in forty four small privately held firms' commercial damage cases in federal courts (Boudreaux and Rao 2007). In the study, the firms' average equity cost of capital exceeds 29.7 percent, with a range of 18 percent to 39 percent. Most estimates were above 24 percent. The average equity cost of capital for the Fortune Five Hundred during this period was approximately 12.8 percent.

A survey of 86 finance professors, many who are forensic economists reveal that a cost of equity capital for small closely held firms should be larger than for a similar large publicly traded business. However, most surveyed economists thought that the premium should be only a few points higher and that an average rate of 29.7 percent seemed extreme and was most likely biased (Boudreaux and Rao 2008). The professors in the survey agreed a 
method that measured the cost of equity capital that captured what the investors at the margin required as a return would be theoretically superior to existing methodologies.

This paper has contributed to the practice of loss estimation by demonstrating the construction of an efficient and theoretically sound methodology that can be used to accurately determine the cost of equity capital for closely held firms involved in business damage litigation. The underlying framework of currently employed valuation techniques was presented, and the explicit reliance of these techniques on various assumptions and speculation based estimation procedures was highlighted.

\section{AUTHOR INFORMATION}

Denis O. Boudreaux is an associate professor at the University of Louisiana at Lafayette and teaches the financial management case course and the MBA advanced finance course. Some of his research interests include capital markets, characteristics of the oil and gas industry, forensic economics, capital budgeting and valuing and measuring the cost of capital of small privately owned firms. He has published in many refereed journals including Business and Economic Review, Journal of Business \& Economics Research, Journal of Petroleum Accounting and Financial Management, and the Journal of Economics and Finance. Dr. Boudreaux is a practicing forensic economist and testifies in personal injury and commercial damage cases.

S.P. Rao is a full professor at the University of Louisiana at Lafayette. He teaches investment and portfolio management courses. His research specialty is in the fields of investments, portfolio theory and capital market efficiency. Dr. Rao has published in many academic journals such as Journal of Business Ethics, Global Finance Journal, Managerial Finance, Southwestern Economic Review, Journal of Economics and Finance, International Business \& Economics Research Journal and the Journal of Accounting and Finance Research.

Nancy C. Rumore is an instructor in Economics at the University of Louisiana a Lafayette. She teaches the fundamentals of economics to non-business and business majors. She has published in many referred journals including The Journal of Financial and Strategic Decisions, The Journal of Bank Cost and Management Accounting, The Journal of Business and Economics Perspectives, Multinational Business Review, Atlantic Economic Journal, Journal of Economics and Finance, and The Journal of Restaurant and Foodservice Marketing.

James H. Underwood III is an associate professor of marketing at the University of Louisiana, Lafayette. He has numerous publications in marketing and business journals. He has served as an expert witness in many business loss and personal injury cases. Among his research interests are forensic marketing and economic analysis, marketing management, marketing research methods, and marketing engineering.

\section{REFERENCES}

1. Boudreaux, Denis and S.P. Rao. "A Review of the Measurement of Cost of Capital in Court Cases" unpublished paper, 2008.

2. Boudreaux, Denis and S.P. Rao. “A Survey of Professors on Measuring a Small Privately Held Firm's Cost of Capital" unpublished paper, 2007.

3. Brigham. Eugene F. and Michael C. Ehrhardt. Financial Management Theory and Practice $\left(10^{\text {th }}\right.$ ed.). Toronto, South-Western 2002.

4. $\quad$ Cost of Capital Chicago" Ibbotson Associates 1998.

5. Quarterly,Damodaran, Aswath. Security Analysis for Investment and Corporate Finance New Jersey: John Wiley \& Sons, 1994.

6. Gaughan, Patrick A. Measuring Business Interruption Losses (2 ${ }^{\text {nd }}$ ed.). New Jersey: John Wiley \& Sons, 2009.

7. Gitman, Lawrence J. Principles of Managerial Finance (7th ed.). New York: Harper Collins 1994.

8. Hitchner, James R. Financial Valuation Applications and Models New Jersey: John Wiley \& Sons, 2006.

9. Internal Revenue Service. Revenue Ruling 59-60, 1959-1, C.B. 237, 1959.

10. Myers, Stewart C., and Stewart M. Turnbull. "Capital Budgeting and the Capital Asset Pricing Model: Good News and Bad News." Journal of Finance 32 (May): 321-332. 
11. Peterson, Renno L. 1989. A Guide to Valuing the Closely Held Business. The Practical Accountant (April): 34-50.

12. Pratt, Shannon P. 1993. Valuing Small Businesses and Professional Practices (2nd ed.).

13. Homewood, IL: Business One Irwin.

14. Pratt, Shannon P. 1998. Cost of Capital: Estimation and Applications. New York: Wiley.

15. Pratt, Shannon P., Robert F. Reilly, and Robert P. Schweihs. 1996. Valuing a Business: The Analysis and Appraisal of Closely Held Companies (3rd ed.). Chicago: Irwin Professional Publishing.

16. Stowe, John D., Thomas R. Robinson, Jerald E. Pinto and Dennis W. McLeavey. Equity Asset Valuation New Jersey: John Wiley \& Sons 2007.

17. Van Horn, James C. 1995. Financial Management and Policy (10th ed.). Englewood Cliffs: Prentice Hall.

18. Weston, J. Fred, and Thomas E. Copeland. 1992. Managerial Finance (9th ed.). Orlando: Dryden Press.

19. Zukin, James H., ed. 1990. Financial Valuation: Businesses and Business Interests (with 1998 Cumulative Index). New York: Warren Gorham \& Lamont/RIA Group. 